\title{
The Development of Teaching Materials for Local Institutional and Cultural Wisdom of North Sumatra Based on Strengthening Ethnics Cultural Values
}

\author{
$1^{\text {st }}$ Trisni Andayani ${ }^{1}, 2^{\text {nd }}$ Ayu Febryani ${ }^{2}, 3^{\text {rd }}$ Nop Berilayani Hia ${ }^{3}, 4^{\text {th }}$ Arya Ginting ${ }^{4}$ \\ \{trisniandayani@unimed.ac.id ${ }^{1}$, ayufebryani@unimed.ac.id ${ }^{2}$, nopberilayanihia@mhs.unimed.ac.id ${ }^{3}$ \} \\ Department of Anthropological Education, Faculty of Social Sciences, Universitas Negeri Medan, \\ Indonesia ${ }^{1,2,3,4}$
}

\begin{abstract}
This study aims to develop teaching materials for the Local Institutional and Cultural Wisdom of North Sumatra based on strengthening cultural values for the students in the Department of Anthropological Education, Universitas Negeri Medan. The type of development research used refers to the 4-D Thiagarajan model, which contains up to the third stage, namely: (a) defining, (b) designing, and (c) developing. The population is all students who have taken courses, while three students determine the sample for individual evaluation, ten students for small group evaluation, and forty students for field testing. The results revealed that the teaching materials were feasible, effective, and valid. The development of teaching materials has been based on Graduate Learning Outcomes and Subject Learning Outcomes. All stages showed the results that the learning tools (Semester Learning Plan and teaching materials) are valid with a score of 4.6 for SLP, and 4.28 for textbooks.
\end{abstract}

Keywords: Teaching materials, Local Institutional/ Wisdom, strengthening cultural values.

\section{Introduction}

Teaching materials are a substansial part of achieving a teaching process. Through the availability of teaching materials, learning can be more directed and learning achievement more easily determined. One form of teaching material is a textbook. Textbooks are an important component in teaching that must be owned and studied by educators and students. According to Mulyasa [1], teaching materials are teaching resources that contain learning messages, which can be used for learning purposes. Therefore, teaching materials are important things that a teacher must own to assist in the smooth teaching and learning process of each subject. Dick, Carey, \& Carey [2] suggest that instructional materials contain the content - either written, mediated, or facilitated by an instructor - that a student will use to achieve the objectives. Teaching materials contain content - written, through the media or facilitated by educators - that students use to achieve learning objectives or expected competencies. Many teaching materials can be used or developed by educators to help students master expected competencies [3][4]. Local wisdom-based education is a reflection for students of study programs based on cultural exploration[5][6].

In the Department of Anthropological Education, Faculty of Social Sciences, Universitas Negeri Medan, in general, the availability of textbooks is still limited. Educators generally use 
popular general books to understand the subject matter. One of the courses that often refers to public books is the Local Institutional and Cultural Wisdom of North Sumatra course, which is found in odd semesters for second-semester students in the independent learning curriculum. Based on the data collected as the initial investigation of the research team, there is no Local Institutional and Cultural Wisdom of North Sumatra textbook for this course. Lecturers have facilitated the students with handout slide presentations adapted from various books containing study materials for these courses. That matter certainly affects the quality of students, both in understanding the lecture material and in practice in the field.

Even though the current learning implementation approach is a scientific approach and contextual teaching-learning, students learn from understanding the surrounding environment[7]. In addition, if explored more deeply, lectures used several supporting books, such as Local Wisdom [8], Environmental Wisdom [9], Folklore [10] and others that are typical of studies from certain regions but do not yet contain wisdom. Ethnic group culture in North Sumatra. These things aroused the interest of researchers to compile a textbook, Local Institutional and Cultural Wisdom of North Sumatra. Moreover, by specializing in strengthening the cultural values of the indigenous ethnic groups of North Sumatra

The North Sumatra region, as one of the provinces in Indonesia, has been known as a multicultural province. The diversity of ethnicities, religions, and races are unity in this province [11]. However, in certain areas still inhabited by the majority of the indigenous population, cultural uniqueness is still clearly felt. This homogeneity becomes self-identity for several community groups and inherent characteristics. For example, understanding the origin of a place (traditional houses, lakes, mountains) can take advantage of the cultural values of ethnic groups as reinforcement.

Research on the development of teaching materials is not a new thing in research development or Research and Development (R \& D). The authors have revealed related to research on the development of teaching materials containing local wisdom values [12] [13] [14] [15]. Among the studies that have discussed the development of teaching materials are, First, research with the title "Development of Teaching Materials for Learning Media Based on Local Wisdom for Mathematics Education Students". Research reveals related to developing teaching materials for learning media based on local wisdom and knowing the quality and feasibility of teaching materials. Through the research development process, mathematics learning tools were obtained through media modules based on valid local wisdom, namely 74.67 [16].

Second, regarding the Effectiveness of Using Interactive Teaching Materials Based on Brebes Local Wisdom in Semantic Courses. The study indicates that in the initial score (pretest) 22 students have not completed and the final score (posttest) on all students have been completed. The effectiveness test results based on the independent samples test table stated that there was a significant difference in the results of the pretest and posttest. Thus, it can be concluded that interactive semantic teaching materials based on Brebes local wisdoms are effectively used in lectures [17].

Third, regarding the Effectiveness of Local Wisdom-Based Teaching Materials as Supporting Fiction Study Courses. As for the findings, based on the output of test statistics, it is known that Asympg.sig. (2-tailed) is worth 0.00. Because the value of $0.00<0.05$, it can be concluded that $\mathrm{Ha}$ is accepted. It can be concluded that there is an effect of using teaching materials based on a local wisdom as a support for the Fiction Studies course for students of the Indonesian Language and Literature Education Study Program [15].

Fourth, regarding the Development of Balinese Ethnoscience Teaching Materials for Prospective Science Teachers. The research findings are described; namely, the material 
feasibility component is $90 \%$ with a very valid category, the presentation feasibility component is $95 \%$ with a very valid category, the practicality component is $96 \%$ in the very valid category, and the readability component is $86.5 \%$ with a very valid category. Overall, the study results indicate that the Balinese Ethnoscience teaching materials that have been developed are feasible to be used theoretically and empirically in the Ethnoscience lecture process[18].

Fifth, the research was about the Development of Local Wisdom-Oriented Listening Teaching Materials to Improve Students' Literacy Skills in Listening Courses. Based on the results and discussion, it can be concluded that teaching materials refer to local wisdom to improve student literacy skills that the results of student responses to the design of teaching materials refer to student worksheets with local wisdom, which were tested on a limited basis to 10 students, showing very valid results with NPr (Percentage Value). ) 90.93\%. Furthermore, the results of expert validation from two expert lecturers showed that the results were quite valid and could be used but needed minor revisions. Implementation of local wisdom worksheet teaching materials to improve student literacy skills in each activity the average value obtained from the four activities is, namely, ; 3.18; 3.23; 3,6; and 3.88 [19].

\section{Method}

In this study, research and development (R\&D) were used using the Thiagarajan model[20]. The development of learning tools from the Thiagarajan, Semmel, \& Semmel model was carried out not until the fourth stage, namely dissemination, considering the limitations of time and research costs. This research was conducted at the Department of Anthropological Education, Faculty of Social Sciences, Universitas Negeri Medan.

The population of this research is all students who have taken the Local Institutional and Cultural Wisdom of North Sumatra course. While the sample is three students for individual evaluation (one-on-one), ten students for small group evaluation, and forty students for the selected field test randomly (random sampling). In addition to students, reviews from four material experts are required.

The stages of this research referring to the stages of R\&D Thiagarajan[20] which are listed in Figure 1. as follows.

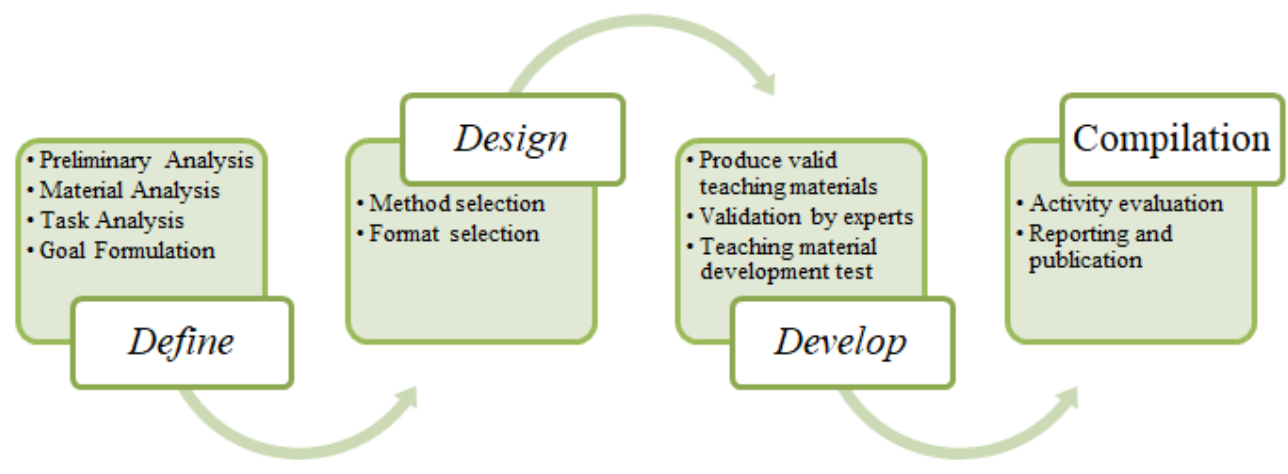

Fig. 1. Stages of research using the Thiagarajan model. 


\section{Results and Discussion}

\subsection{Concepts Contained in Teaching Materials Local Institutional and Cultural Wisdom of North Sumatra Courses}

The Local Institutional and Cultural Wisdom of North Sumatra course provides the ability to understand and develop institutional studies and local wisdom for each ethnic group in Indonesia and North Sumatra. In this course, students are also equipped to understand, apply, analyze, and apply various institutions/ local cultural wisdom in North Sumatra. In addition, students are expected to study, analyze, build knowledge related to types, forms, values, dimensions, and examples of local wisdom in North Sumatra. Furthermore, students can analyze and review the results of local wisdom studies based on region and the environment, either directly in the community or by utilizing digital data and information. Finally, students are expected to design, implement, and write the results of institutional research/local wisdom in North Sumatra and examine the existence, dynamics, and solutions in implementing their conservation strategies, either independently or in groups responsibly.

In module 1, the discussion is related to the nature of institutions and local wisdom, tasks, and the urgency of local institutions. This initial concept needs to be understood together as a basis for students to understand further the following materials in this course. This subject should not be a new thing for students in the second semester. The lecturers in the previous semester have mentioned about the term local wisdom, such as introduction to anthropology, Indonesian ethnography, and Indonesian Socio-Cultural System. However, as a candidate for a reliable anthropologist, the conceptual nature of institutions and wisdom must be understood in depth. In addition, to become good anthropology teachers, students are expected to have basic anthropology learning so that anthropology learning is understood practically and conceptually, and theoretically. For this reason, students must be able to understand various institutions/ local cultural wisdom in North Sumatra.

Discussion in module 2 is the function and role of local institutions in community development in various sectors of local wisdom. This material contains the functions of customary and local institutions, the role of local institutions in community development in various sectors of local wisdom, and various local institutions in North Sumatra.

The discussion in module 3 contains the types, forms, and values of local cultural wisdom in North Sumatra. In detail describes the governance, customary values, procedures for activities, and a selection of space or place while the forms cover tangible local wisdom and intangible local wisdom. Finally, reviewing examples of the application of local wisdom values in North Sumatra.

In module 4, the material studied by students is the dimensions of local wisdom, which describe clearly about dimensions of local knowledge, dimensions of local values, dimensions of local skills, dimensions of local resources, dimensions of local decision-making, and dimensions of local group solidarity. In addition, the material also contains the study of local wisdom based on disaster mitigation in North Sumatra.

In module 5, the discussion is about local wisdom by region (spatial) in North Sumatra. The division consists of local wisdom based on nature, mountains, rivers, hills, valleys, forests, spirits, wild forest animals, or sacred/sacred animals. While module 6 discusses the cultural heritage of North Sumatra. The description is about the meaning of cultural heritage, physical cultural heritage, intangible cultural heritage, the domain of intangible cultural heritage, physical cultural heritage and intangible cultural heritage in North Sumatra, and the nomination of intangible cultural heritage by UNESCO. 
Module 7 contains the role of institutions/local wisdom in environmental management. The review is the environment and its relationship with humans and traditional institutions as regulators of natural resources in North Sumatra. Finally, module 8 reviews the existence of local institutions and the dynamics of local knowledge and modern knowledge systems. In detail, it discusses the challenges and efforts to preserve local institutions, the dynamics of local knowledge systems and modern knowledge systems, and strategic solutions for the preservation of local wisdom institutions in North Sumatra in the global era.

\subsection{Implementation of Teaching Materials Based on Strengthening Ethnic Cultural Values of North Sumatra}

Applying the model for strengthening ethnic, cultural values in North Sumatra is an substantial part of achieving a graduate profile in the Department of Anthropological Education. One of strengthening can be done in strengthening various courses. Local Institutional and Cultural Wisdom of North Sumatra is one courses at the Department of Anthropological, which focuses on examining various wisdom values contained in every cultural activity of each ethnic group. The values of local wisdom are identified through cultural activities of each ethnic group, such as strengthening local identity, indigenous knowledge, ecological knowledge, cultural activities, and artefacts or cultural objects.

The model for strengthening the cultural values of North Sumatra can be implemented through various forms of assignments contained in the Indonesian National Qualification Curriculum (INQC) which is correlated with the Merdeka Learning Curriculum. As one of the universities that focus on implementing this curriculum, Universitas Negeri Medan juxtaposes its implementation with six assignments. These six assignments can be away, and a means for students to strengthen the values of local wisdom typical of North Sumatra.

\subsection{Development of Local Institutional and Cultural Wisdom Teaching Materials of North Sumatra}

From the research carried out, both from preparation, making folklore teaching materials and oral traditions, it is carried out by following the steps of developing the Thiagarajan [20], Semmel and Semmel models consisting of three stages, namely defining, designing, developing as follows:

Defining Stage. The definition phase includes the front-end analysis phase, student analysis, task analysis, material analysis, and formulation of learning outcomes. The research results obtained at the definition stage will be described below.

Front End Analysis. Learning tools are important components that determine student success in learning material. Based on the researcher's observations, learning in the Local Institutional and Cultural Wisdom of North Sumatra course was not optimal because previously, learning was sourced from course instructors, lecturers rarely used cooperative learning models. Learning was still centered on the lecturer. The teaching materials used by the lecturers are general teaching materials that are deemed insufficient to provide a complete understanding to students, especially when using a scientific approach. Students certainly need to know and explore various Local Institutional and Cultural Wisdom in the area around their homes and other ethnic groups. In addition, the learning of the Local Institutional and Cultural Wisdom of North Sumatra was previously conceptual and contained little practicality. But it has not been 
linked to strengthening ethnic, cultural values in North Sumatra so that in the learning process, it has not been seen explicitly strengthening the students. For this reason, it is necessary to develop teaching materials based on strengthening the values of local wisdom originating from the culture of ethnic groups in North Sumatra.

Student and Environmental Analysis. Student analysis was carried out to determine the 2020 batch students' heterogeneity in the Department of Anthropological Education, Faculty of Social Sciences, Universitas Negeri Medan. Student analysis is carried out by taking into account the characteristics, abilities, and experiences of students individually and in groups. Analysis carried out includes background knowledge, socioeconomic, and ethnicity. The results of student analysis are as follows.

a) Based on gender, students in Class A Regular 2020, consisting of 5 males and 22 females, and 13 students who have taken the Local Institutional and Cultural Wisdom of North Sumatra course.

b) Based on ethnicity, students consist of 26 Toba Batak students, 3 Mandailing students, 1 Pakpak ethnic student, 3 Nias Ethnic students, 5 Karonese students, and 2 Simalungun students.

c) Based on their ethnicity, $88.5 \%$ of students answered that they understood their ethnicity, and $78 \%$ of students understood other ethnicities, although not holistically. Students know their culture and other ethnic cultures even though they are not optimal.

d) Students are used to working on KKNI assignments even with many assignments from various lecturers, and in general, they can get scores above 80 .

Some students have good cognitive and socio-cultural abilities, as evidenced by the ability of students to interact easily despite different ethnicities and religions. However, even though their cognitive abilities are good, students are less thorough in completing assignments and providing responses to discussion sessions for each material. In addition, during the COVID-19 pandemic like this, students have difficulty gaining easy access to offline literature and limited costs in deepening their knowledge of each material.

Material Analysis. The material analysis determined the primary materials based on Graduate Learning Outcomes (GLO) and Subject Learning Outcomes (SLO). This activity aimed for learning to achieve the GLO and SLO that have been set.

Task Analysis. The task analysis identified that the main competencies that need to be taught to students are the GLO, SLO, and sub-SLO Local Institutional and Cultural Wisdom of North Sumatra.

Formulation of Learning Objectives. The results of the task analysis are then used as a reference to formulate the following learning objectives.

1) Students can describe the nature of institutions and local wisdom, tasks, and the urgency of local institutions.

2) Students can identify the functions and roles of institutions in community development in various sectors of local wisdom.

3) Students can analyse the types, forms, and values of local cultural wisdom in North Sumatra.

4) Students can analyse the dimensions of local Wisdom and Study Local Wisdom based on Disaster Mitigation. 
5) Students can analyse the study of local wisdom by region/spatial/area in North Sumatra Sumatera.

6) Students can analyse the Cultural Heritage in North Sumatra.

7) Students can analyse the role of institutions/local wisdom in environmental management.

8) Students can analyse the existence of local institutions and the dynamics of local knowledge systems with modern knowledge systems.

9) Students can formulate strategic solutions for institutional preservation of ethnic local wisdom in North Sumatra in the global era.

Design Stage. After getting the results of the analysis in the previous stage, designing teaching materials were developed based on the results of the analysis at the defining stage. Furthermore, instruments that support the stages of this activity are also prepared. Team prepared and developed a Semester Learning Plan (SLP), Lecture Contract, teaching materials, student worksheets, and an assessment matrix.

Test Compilation. The test is arranged based on the learning outcomes of the subjects taught in the learning objectives. The question test is a test of the ability to explore various ethnic cultures in North Sumatra, adjusted to the study material/material for each meeting.

Media Selection. Based on the front-end and environmental analysis results, the media of teaching materials containing local wisdom values typical of ethnic culture in North Sumatra and learning support devices were selected as a means of delivering material and as one of the student task's responsibilities. Team arranged teaching materials by taking into account the values of local wisdom that will be studied to allow students to explore their abilities.

Format Selection. The selection of the SLP format and the lecturing contract used in this study refers to the KKNI curriculum in the Universitas Negeri Medan format by adjusting to the relationship between tasks and SLO Local Institutional and Cultural Wisdom of North Sumatra. The learning content refers to the results of the material analysis, the results of the task analysis, and the results of the analysis of learning objectives formulated in the defining stage.

Initial Design. This activity is the writing of learning tools: lesson plans, lecture contracts, textbooks containing material on Local Institutional and Cultural Wisdom of North Sumatra by strengthening the values of local wisdom typical of ethnic groups in North Sumatra.

Development Stage. Team determined two series of activities at this stage, namely validation by experts and testing product quality.

Expert Validation. Expert assessment includes product validation, which includes teaching materials and learning tools developed at the design stage. Four competent people carry out validation to assess the feasibility of teaching materials and learning tools. After receiving the improvement results according to the validators' instructions, the overall average value was 4.44. This value shows good results and can be used with minor revisions.

Development Trial. The development trials that have been carried out consist of testing learning tools (teaching materials and semester lesson plan) and learning achievement trials (student assignment results) which all show good results. 
Validation Results. The results of expert validation of mathematics teaching materials containing character education and learning support devices are obtained in Table 1 as follows.

Table 1. Recapitulation of Validation Results.

\begin{tabular}{|l|c|c|c|c|c|c|}
\hline \multirow{2}{*}{ Learning Media } & \multicolumn{4}{|c|}{ Validator Average } & \multirow{2}{*}{ Average } & \multirow{2}{*}{ Criteria } \\
\cline { 2 - 5 } & I & II & III & IV & & \\
\hline Semester Lesson Plan & 4.70 & 4.60 & 4.50 & 4.60 & 4.60 & Valid \\
\hline Teaching materials & 4.20 & 4.20 & 4.40 & 4.35 & 4.28 & Valid \\
\hline
\end{tabular}

Based on Table 1, it can be seen that for the validation of learning tools from the four validators, the average RPS validation is 4.60 , and the validation of teaching materials is 4.28 out of a maximum value of 5 .

Based on comments and suggestions from the validators, further evaluation and revision were made to teaching materials and supporting devices.

\section{Conclusion}

This study concluded that teaching materials based on strengthening ethnics cultural values in North Sumatra have been implemented through various forms of assignments contained in the Indonesian National Qualifications Curriculum (INQC). These tasks are routine assignments, Critical Book Reports, Critical Journal Reports, Mini Research, Idea Engineering, and Project Reports. In addition, students work on various assignments through searching various literature from native ethnic groups of North Sumatra, namely the Toba Bataknese, Karonese, Simalungun, Pakpak, Angkola, Mandailing, Malay, and Nias ethnic groups.

The research results at the defining stage were determined by front-end, student and environmental, task, and material analysis. Furthermore, there is a formulation of learning outcomes. At the front-end analysis stage, team finished Semester Lesson Plan (SLP) and teaching materials based on strengthening cultural ethnics' values in North Sumatra. At the student and environmental analysis stage, data was obtained that the students consisted of 27 students from the class of 2020 who are currently taking the Local Institutional and Cultural Wisdom of North Sumatra course, and 13 students who have taken courses in 2019/2020.

In material analysis, various teaching materials were identified under the determination of the Department of Anthropological Education Graduate Learning Outcomes, Course Learning Outcomes, and Subject Learning Sub Outcomes. The task analysis is determined from the formulation of learning objectives at each meeting. The test preparation stage, format selection, and initial design are based on indicators of competency achievement (learning achievement), which means that teaching material media must contain local wisdom values typical of ethnic culture in North Sumatra.

The trial results at the development stage showed a result of 4.60 on a scale of 5 for the SLP. Then, it was 4.28 on a scale of 5 for teaching materials. Testing of teaching materials can be seen from whether or not the quality of work assignments and quiz reviews for each 
meeting on the material presented increases. Lectures can use this textbook in their teachinglearning process.

This research suggests the need to refocus on each element of the learning device (Semester Lesson Plan and teaching materials) so that it is under the model of strengthening the values of local wisdom typical of North Sumatra.

Acknowledgments. The Autors would like to thank The Research and Community Service Centre (LPPM) of Universitas Negeri Medan for the funding provided so that this research can be completed properly.

\section{References}

[1] Mulyasa. Pengembangan dan Implementasi Kurikulum 2013. Bandung: Remaja Rosdakarya; 2013.

[2] Dick W, Carey L, Carey JO. The Systematic Design of Instruction. $7^{\text {th }}$ Edition. New Jersey: Pearson Education, Inc; 2009.

[3] Wardani IGAK. Penelitian Tindakan Kelas. Tangerang: Universitas Terbuka; 2014.

[4] Suparman M. Desain Instruksional. Jakarta: Pusat Penerbitan Universitas Terbuka; 2004.

[5] Mardhatillah, Verawati, Eviyanti E, Pramuniati I, Ramadhani F. Teaching Materials Based on Local Wisdom to Create Meaningful Learning in Aceh Province. Advances in Social Science, Education and Humanities Research. Proceedings of the $1^{\text {st }}$ International Conference on Social Sciences and Interdisciplinary Studies; $14^{\text {th }}-15^{\text {th }}$ November 2018; Medan. Atlantis Press; 2019. p. 101-105.

[6] Pingge HD. Learning materials based on local wisdom of Sumbanese as the source of learning in elementary school. Proceeding the $4^{\text {th }}$ International Seminar on Social Studies and History Education; $5^{\text {th }}$ November 2019; Bandung. Bandung: Universitas Pendidikan Indonesia; 2019. p. 121-131.

[7] Nurjannah, Simarmata T, Supsiloani, Andayani T, Febryani A, Amal BK. The Implementation of Local Wisdom Education Global Insights in Institutional and Local Wisdom of Culture in North Sumatera Subject in Faculty of Social Science,Universitas Negeri Medan. Advances in Social Science, Education and Humanities Research. Proceedings of the $1^{\text {st }}$ International Conference on Social Sciences and Interdisciplinary Studies; $14^{\text {th }}-15^{\text {th }}$ November 2018; Medan. Atlantis Press; 2019. p. 138-143.

[8] Sumintarsih, et al. Kearifan Lokal. Yogyakarta: Balai Pelestarian Nilai Budaya DIY; 2013.

[9] Anshoriy MN. Kearifan lingkungan dalam Perspektif Budaya Jawa. Jakarta: Yayasan Obor Indonesia; 2008.

[10] Jauhari H. Folklor - Bahan Kajian Ilmu Budaya, Sastra, dan Sejarah. Bandung: Yrama Widya; 2018.

[11] Febryani A, Puspitawati, Andayani T, Fimansyah W. Folklor: Penguatan Nilai - Nilai Kearifan Lokal Khas Sumatra Utara. Banten: CV. A.A.Rizky; 2020.

[12] Syahrul S, Arifin A, Datuk A, Almu FF, Ramlah S. Pengembangan Bahan Ajar Berorientasi Literasi Kearifan Lokal di Mas Al-Hikmah Soe Nusa Tenggara Timur. J Pemberdaya Masyarakat. 2019; 4(2):371-379.

[13] Lestariningsih N, Suardiman SP. Pengembangan Bahan Ajar Tematik-Integratif Berbasis Kearifan Lokal Untuk Meningkatkan Karakter Peduli Dan Tanggung Jawab. J Pendidik Karakter. 2017; 7(1):86-99.

[14] Satriawan M, Rosmiati R. Pengembangan Bahan Ajar Fisika Berbasis Kontekstual Dengan Mengintegrasikan Kearifan Lokal Untuk Meningkatkan Pemahaman Konsep Fisika Pada Mahasiswa. J Penelit Pendidik Sains. 2017; 6(1).

[15] Sulastri S, Simarmata MY, Hartati M. Keefektifan Bahan Ajar Berbasis Kearifan Lokal sebagai Penunjang Mata Kuliah Kajian Fiksi. Cakrawala Linguist. 2019; 2(1):1-8.

[16] Ferdianto F, Setiyani S. Pengembangan Bahan Ajar Media Pembelajaran Berbasis Kearifan Lokal Mahasiswa Pendidikan Matematika. J Nas Pendidik Mat. 2018; 2(1):37. 
[17] Kurniawan PY. Keefektifan Penggunaan Bahan Ajar Interaktif Yang Berbasis Kearifan Lokal Brebes Dalam Mata Kulia Semantik. J Pendidik Bhs dan Sastra Indones. 2019; 3(2):170-176.

[18] Sarini P, Selamet K. Pengembangan Bahan Ajar Etnosains Bali bagi Calon Guru IPA. Wahana Mat dan Sains J Mat Sains, dan Pembelajarannya. 2019; 13(1):27-39.

[19] Pujiatna T, Rosmaya E, Wahyuningsih N. Pengembangan Bahan Ajar Simak Berorientas Kearifan Lokal untuk Meningkatkan Kemampuan Literasi Mahasiswa pada Mata Kuliah Menyimak. Deiksis J Pendidik Bhs dan Sastra Indones. 2020; 7(1): 91.

[20] Thiagarajan S, Semmel DS, Semmel MI. Instructional Development for Training Teachers of Exceptional Children. Indiana: Indiana University Bloomington; 1974. 